\title{
Razvoj enzimskog potencijala različitih namjenskih sorti ječma tijekom slađenja
}

\begin{abstract}
Sažetak
Razvoj enzimske aktivnosti zrna ječma tijekom procesa slađenja je jedno od ključnih zbivanja kojom se osigurava zadovoljavajuća tehnološka kvaliteta slada. Brojna istraživanja su provedena na ovu temu kojima je ustanovljeno da se najbolji rezultati vezani za razvoj enzimskog potencijala zrna osiguravaju slađenjem namjenskih, jarih, dvoredih pivarskih sorti uz odgovarajući režim slađenja kojim se osiguravaju procesni uvjeti koji pogoduju aktiviranju već u zrnu prisutnih i/ili de novo sintezi enzima. Cilj ovog istraživanja bilo je ustanoviti kako s obzirom na gore postavljene zahtjeve reagiraju različite namjenske, dvorede, jare i ozime sorte ječma koje se uobičajeno koriste za proizvodnju slada u Hrvatskoj. Temeljem dobivenih rezultata ustanovljeno je aktivnost $\alpha$-amilaze u svim ispitivanim sortama bila je unutar, dok je aktivnost b-amilaze u sve tri sorte bila je viša od standardnih vrjednosti za svijetli slad. Oba enzima su pokazala najvišu aktivnost zadnjeg, četvrtog dana klijanja. Proces sušenja slada značajno više smanjuje aktivnostb-amilaze(25-30\%) negoa-amilaze(oko 10\%). Utvrđivanisuiostalipokazateljikvalitetepolaznih ječmova, procesa mikroslađenja i gotovih sladova. Ustanovljeno je da sve tri sorte daju svijetli pivarski slad vrlo dobre kvalitete. Neki pokazatelji kvalitete slada poput topljivog dušika u sladovini i viskoznosti su imali izvrsne vrijednosti, najproblematičniji pokazatelj je bila fiabilnost. Međutim, kako je friabilnost kumulativni pokazetelj na koji utječu brojni pojedinačni faktori ovo zahtijeva dodatna istraživanja.

Ključne riječi: namjenske sorte ječma, alfa-amilaza, ukupna dijastatska snaga, mikroslađenje
\end{abstract}

\section{Uvod}

Tijekom slađenja treba osigurati razgradnju komponenti zrna ječma na način da ta razgradnja intenzivna dovoljno da bi zadovoljila zahtjeve pivarske industrije, tj. da bi se dobile zadovoljavajuće pivarske performance. Konverzija škroba u topljive niskomolekulske, fermentabilne sastojke je kvantitativno najvažnije zbivanje tijekom ukomljavanja. Konverzija škroba iz endosperma ječmenog zrna do glukoze i maltoze tijekom ukomljavanja je katalizirana zajedničkim djelovanjem amilolitičkih enzima slada (amilolitički enzimski kompleks) koji hidrolizira $\alpha-(1 \rightarrow 4)$ i $\alpha-(1 \rightarrow 6)$ veze između glukoza povezanih u lance koji tvore molekulu škroba. Ukupna aktivnost amilolitičkih enzima uobičajeno se naziva ukupna dijastatska snaga slada ili sposobnost samoošećeranja (DP, diastatic power) i u najvećem obuhvaća aktivnost $\beta$-amilaze (Duke i Henson, 2009). Ova aktivnost treba osigurati dostatnu koncentraciju fermentabilnih šećera koje će kvasac metabolzirati tijekom umnažanja i potom previranja u procesu alkoholnog vrenja sladovine (Bamforth, 2006). Skupina enzima koji ovo osiguravaju, tj. doprinose ukupnoj dijastatskoj snazi slada su $\alpha$-amilaza, $\beta$-amilaza, granična dekstrinaza (tj. R-enzim ili pululanaza koji je enzim za razgradnju $\alpha$-1,6 glikozidnih veza amilopektina), i $\alpha$-glikozidaza (Duedahl-Olesen i sur., 2000). Ukupni DP je ponajviše zavisan od aktivnosti $\beta$-amilaze, enzima koji ima najveću aktivnost u sladu tijekom ukomljavanja tj. kada mu je otopljeni škrob supstrat (Doehlert i Duke, 1983; Sun i Henson, 1991; Evans i sur., 2005; Henson i Duke, 2008). $\alpha$-amilaza i $\alpha$-glukozidaza djeluju sinergijski u razgradnji šrkoba do šećera pri čemu djeluju učinkovitije nego svaki enzim ponaosob (Sun i Henson, 1990). Kad je supstrat nativni škrob endosperma ječma $\beta$-amilaza i granična dekstrinaza ponajviše zavise od djelovanja $\alpha$-amilaze koja osigurava dovoljan broj ne- 
reducirajućih krajeva dekstrina nastalih razgradnjom škroba, na koje ovi enzimi mogu djelovati (Sun and Henson, 1990, 1991)(7,8). lako se radi o dva vrlo različita enzima s obzirom na njihovo sinergijsko djelovanje na koncentraciju fermentabilnih šećera tijekom ukomljavanja $\boldsymbol{\alpha}$-i $\beta$ amilazu trebamo zajednički promatrati u svjetlu kvalitete gotovog slada. Pri tome treba imati u vidu da je aktivnost $\alpha$-amilaze brža od aktivnosti $\beta$-amilaze, koje je puno sporija pa prema tome i limitirajući faktor procesa potpune saharifikacije škroba. $\alpha$-amilaza ima osam puta brže

djelovanje od $\beta$-amilaze (Doehlert i sur.,1982).

Enzim $\alpha$-amilaza (EZ 3.2.1.1) nastaje tijekom klijanja zrna ječma (Hordeum vulgare L.). Kako se sintetizira tijekom klijanja zrna, njegova aktivnost pretežito je genotipski determinirano svojstvo sorte, mada su i procesni uvjeti tijekom ukomljavanja važni za ispoljavanje njegove aktivnosti. Sukladno rečenom jedna od osnovnih poželjnih svojstava dobre pivarske sorte je što veća aktivnost $\alpha$-amilaze u sladu. $\alpha$-amilaza je jedini pojedinačni enzim čija se aktivnost određuje kao pokazatelj kvalitete slada prema relevantnim analitičkim metodama za određivanje kvalitete slada EBC (European Brewrey Convention) i ASBC (American Society of Brewing Chemist) i loB (The Institute of Brewing). Razlog ovome leži u važnosti svojstva ovog enzima da hidrolizira škrob do dekstrina. Međutim još nije posve rasvjetljena uloga svakog pojedinačnog amilolitičkog enzima u priskrbljivanju fermentabilnih šećera u sladovini. Briggs, 1998 drži izuzetno značajnim uvjete ukomljavanja za djelovanje ukupnog enzimskog kompleksa (uključujući i amilolitički), naručito u uvjetima prisutnosti više supstrata u komini. Utvrditi aktivnost kojeg od enzima amilolitičkog kompleksa ječma i slada je najbolja za predikciju koncentracije fermentabilnih šećera u sladovini može biti jedan od osnovnih pokazatelja selekcionarima za poboljšanje sladarskih svojstava pojedine sorte. Međutim za početnu procjenu pogodnosti neke sorte da postane pivarska dovoljno je i praćenje aktivnosti $\alpha$-amilaze i ukupne dijastatske snage slada. Cilj ovog rada bio je: 1 ) ustanoviti aktivnost $\alpha$-amilaze i ukupne dijastatske snage slada $\mathrm{u}$ ispitivanim namjenskim sortama: i) jarog, dvoredog pivarskog, ii) ozimog, pivarskog ječma, te iii) ozimog, pivarsko-stočnog dvoredog ječma i usporediti sa preporučenim vrijednostima za kvalitetan svijetli pivarski slad; 2 ) usporediti aktivnosti $\alpha$-amilaze i ukupne dijastatske snage slada tijekom pojedinih dana klijanja i u gotovom sladu nakon sušenja

\section{Materijali i metode}

Za ispitivanje su odabrane tri različite namjenske sorte ječma PI Osijek: Pivarac (jara dvoreda pivarska sorta, B s-tr); Vanessa (ozima dvoreda sorta, B w-tr); i Lukas (višenamjenska pivarsko/stočna, ozima, dvoreda sorta, B/Fe $w$-tr). Sve ispitivane sorte su dobivene iz sortnih pokusa provedenih pod istim uvjetima i na istoj lokaciji Osijek iz sezone 2018. godine, kako bi se maksimalno osigurao jednak utjecaj ekoloških i agrotehničkih faktora na njih. Uzorkovanje, čišćenje i dorada ječma je obavljena prema preporučenoj EBC metodi 3.3.1 (EBC Analytica, 1998). Uzorci dorađenog, netretiranog ječma (10 kg svake sorte) su pohranjeni u dvoslojne papirnate vrećice i čuvani na suhom mjestu, dva mjeseca da bi se prevladala postžetvena pospanost ("post-harvest grain dormancy"). Mikrobiološka ispravnost zrna ispitana je samo na prisutnost Fusarium graminearum i Fusarium culmorum prema metodi MEBAK 2.6. (Middle European Brewing Analysis Commission), 3.ed. Band I (MEBAK, 2011). Mikroslađenje (namakanje i klijanje) provedeno je $u$ inkubatoru s kontroliranom atmosferom (Climatic test chamberClimacell 222, Memmert) (Tablica 1.). Sušenje slada provedeno je u sušnici s programiranim režimom rada (Memmert UN 30). Parametri svih faza mikroslađenja su podešeni prema standardnoj MEBAK shemi za slađenje ječma i prikazani u tablici 2. Otklicavanje dobivenih sladova (uklanjanje korjenčića i sladne klice) je izvršeno ručno, prosijavanjem kroz sito za korjenčiće. Slad je pohranjena na suho mjesto 30 da se stabiliziraju enzimi i udjel vlage. Određivani polazni pokazatelji kvalitete ječma i pokazatelji kvalitete samog postupka mikroslađenja (Tablice 3 i 4), prema analitici MEBAK (MEBAK, 2011). Analiza kvalitete polazne kvalitete ječma, mikroslađenja i gotovog slada (Tablica 4.) izvršene su prema analitici MEBAK (2011). Zbog malog broja 
sorti rezultati su dani kao prosjek tri mjerenja, izuzev za aktivnost $\alpha$-amilaze i ukupnu dijastatsku snagu gdje je izraženi rezultat prosjek dvaju mjerenja. aktivnost $\alpha$-amilaze određena je prema EBC metodi 4.13. (EBC Analytica, 1998). Princip određivanja zasniva se na tome da se dodatkom $\beta$-amilaze u suvišku u standardnu otpopinu škroba (otopinu graničnih dekstrina). $U$ ovu otopinu se unosi ekstrakt slada čija $\alpha$-amilaza razgrađuje granične dekstrine. Vrijeme koje je potrebno da se nakon dodatka otopine joda uspostavi standardno obojenje škroba i joda nosi naziv "jedinica nastajanja dekstrina ili DU“. Ona predstavlja mjeru za procjenu aktivnosti $\alpha$-amilaze ispitivanog slada. Analiza je izvršena pomoću "malt-amylase kit" K-MALT-A (Megazyme Int. Bray, Irska). Smatra se da je standardna vrijednost za aktivnost $\alpha$-amilaze 40-70 DU. Ukupna dijastatska snaga slada određena je spektrofotometrijskom metodom EBC 4.12.1. (EBC Analytica, 1998). Princip ove metode je da se puferiranoj otopini slada doda je alikvotni ekstrakta slada dobivenog na niskoj temperaturi, te se nastala smjesa temperira 30 min na 20 ${ }^{\circ} \mathrm{C}$. Potom se jodometrijski određuje količina nastale maltoze koja se iz dekstrina (prethodno nastalih djelovanjem $\alpha$-amilaze) sukcesivno oslobađa djelovanjem uglavnom $\beta$-amilaze. Analiza je izvršena pomoću "beta-amylase kit" K-BETA-3 (Megazyme Int. Bray, Irska). Standardne vrijednosti za svijetli slad je 240-260 ${ }^{\circ} \mathrm{WK}$.

Tablica 1. Shema slađenja uzoraka ječma/

Table 1. Micromalting sheme of barley samples

\begin{tabular}{|c|c|}
\hline $\begin{array}{l}\text { 1. dan/ } \\
1^{\text {st }} \text { day }\end{array}$ & $\begin{array}{l}\text { Močenje pod vodom } 5 \mathrm{~h}, \mathrm{t}=14,0^{\circ} \mathrm{C} / \\
\text { Immersion steeping for } 5 \mathrm{~h}, \mathrm{t}=14,0^{\circ} \mathrm{C} \text {; } \\
\text { Stanka na zraku } 19 \mathrm{~h}, \mathrm{t}=14,5^{\circ} \mathrm{C} / \\
\text { Dry steeping for } 19 \mathrm{~h}, \mathrm{t}=14,5^{\circ} \mathrm{C}\end{array}$ \\
\hline $\begin{array}{l}\text { 2. dan/ } \\
2^{\text {nd }} \text { day }\end{array}$ & $\begin{array}{l}\text { Močenje pod vodom } 4 \mathrm{~h}, \mathrm{t}=14,0^{\circ} \mathrm{C} / \\
\text { Immersion steeping for } 4 \mathrm{~h}, \mathrm{t}=14,0^{\circ} \mathrm{C} \text {; } \\
\text { Stanka na zraku } 20 \mathrm{~h}, \mathrm{t}=14,5^{\circ} \mathrm{C} / \\
\text { Dry steeping for } 20 \mathrm{~h}, \mathrm{t}=14,5^{\circ} \mathrm{C}\end{array}$ \\
\hline $\begin{array}{l}\text { 3. dan/ } \\
3^{\text {rd }} \text { day }\left({ }^{*}\right)\end{array}$ & $\begin{array}{l}\text { Močenje pod vodom } 2 \mathrm{~h}, \mathrm{t}=14,0^{\circ} \mathrm{C} / \\
\text { Immersion steeping for } 2 \mathrm{~h}, \mathrm{t}=14,0^{\circ} \mathrm{C} \text {; }\end{array}$ \\
\hline $\begin{array}{c}\text { 3. }-7 . \text { dan/ } \\
3-7 \text { day }\end{array}$ & $\begin{array}{l}\text { Klijanje je provedeno pri } 14,5{ }^{\circ} \mathrm{C} \text { kroz } 4 \text { dana uz relativnu vlažnost zraka r.H. }=95 \% \text {; } \\
\text { Germination was carried out at } 14,5{ }^{\circ} \mathrm{C} \text { during } 4 \text { days on relative humidity of air in each } \\
\text { procedure: r.H. = 95-97\%; } \\
\text { uzorci su izdvajani svaki dan tijekom klijanja/ } \\
\text { sampling during germination was performed daily }\end{array}$ \\
\hline $\begin{array}{l}\text { 8. dan/ } \\
8^{\text {th }} \text { day }\end{array}$ & $\begin{array}{l}\text { Sušenje je trajalo } 19 \mathrm{~h} \text { prema standardnoj MEBAK proceduri, po završetku je slad otklicana, } \\
\text { odvagana i spremljena u papirnate vrećice/ } \\
\text { Duration of kilning was } 19 \mathrm{hr} \text {, performed according to standard procedures for pale malt } \\
\text { (MEBAK) after last hour of germination, draying finished, malt degermination, measuring and } \\
\text { packing ih paper bags and storaged }\end{array}$ \\
\hline
\end{tabular}

$\left({ }^{*}\right)$ kontrola stupnja namočenosti na početku traćeg dana provjeravana je nakon svakog sata močenja pod vodom $\mathrm{i}$ kad ustanovljeno da zrno više ne može podnijeti daljnje močenje vlažnost zrna od 44,5\% podešena je orošavanjem u klijalištu (1 dan klijanja)/(*) control of the degree of soaking at the beginning of the third day and every hour of soaking under the water, when it was found that the grain does not tolerate any further soaking under water, moisture content of $44,5 \%$ was adjustment with sparging (spray steeping) ) in germination box ( $1^{\text {st }}$ day of germination)

\section{Rezultati i rasprava}

Na kvalitetu zrna se može značajno utjecati podešavanjem procesnih parametara tijekom slađenja kako bi se osigurale ciljane vrijednosti određenih važnih pokazatelja kvalitete slada. Međutim, vrlo je teško (zapravo nemoguće) optmirati postupak slađenja po više parametara kvalitete jer se neki međusobno isključuju (npr. duboku razgradnju $\beta$-glukana redovito prati pojačana proteoliza i dr.), pa se pivari pouzdaju u dokazane sorte ječma koje su se etablirale 
kroz dobra pivarska svojstva tijekom dugog niza godina. Kod ovih sorti se na temelju tih podataka može izvršiti relativno pouzdana predikcija konačne pivarske kvalitete temeljem rezultata za analize polaznog ječma, procesa mikroslađenja i gotovog slada. $U$ novije vrijeme se na tržištu pojavilo dosta novih ozimih dvonamjenskih sorti (pivarsko-stočne, B/Fe). Neke od njih pokazale su se dobre u smislu njihove prihvatljivosti sa pivarskog stajališta, poput udjela $\beta$-glukana, proteina, friabilnosti, udjela staklastih zrna i dr. Zbog toga su prihvaćene kao pivarsko-stočne sorte (Kunze, 2011). Ove sorte dvonamjenskog, dvoredog, ozimog ječma imaju visok prinos (+30\%), u usporedbi sa jarim dvoredim sortama, te su tako atraktivnije uzgajivačima, a karakterizira ih visok ekstrakt i niža boja slada, ali i niži enzimski potencijal u odnosu na šestoredne sorte (Gupta i sur., 2010). Nakon ulaska u Europsku Uniju Hrvatska nije raspolagala domaćim striktno pivarskim sortama, a tržište se otvorilo za slobodan uvoz namjenskih, pivarskih sorti ječma. Za etabliranje dobre pivarske sorte treba poznavati njezina sladarska svojstva kroz statistički relevantan niz godina (najmanje 3, poželjno godina, pa i više). Zbog toga je nadležno tijelo za priznavanje sorti u Republici Hrvatskoj dopustilo je registraciju pojedinih sorti kao višenamjenskih (npr. pivarsko-stočnih). Pored toga Poljoprivredni institut Osijek izbacio je na tržište jaru, pivarsku sortu ječma Pivarac kao domaću sortu velikog potencijala za industriju proizvodnje slada. Kako bi se neka sorta mogla objektivno ocijeniti potrebno je usporediti ju sa pivarskom sortom koja se koristi kao standard u nizu zemalja i ima dobro poznata i relativno stalna sladarska svojstva što je u ovom istraživanje bila sorta Vanessa. Težište ovog istraživanja je bilo u procjeni enzimskog potencijala domaćih pivarskih sorti iz dva razloga: i) RH se nalazi u klimatskom području gdje je pred kraj vegatacijskog perioda ječma vrlo čest fenomen prisilnog sazrijevanja" ("forced maturation", "accelerated aging"), koji ima nepovoljan učinak na brojne pokazatelje kvalitete zrna gotovo svih žitarica pa tako i ječma. Osobito se odražava na nižu enzimsku aktivnost zrna ječma (Tabatabaei, 2015); ii) dvonamjenske sorte ječma (pivarsko-stočne) su po pokazateljima kvalitete su općeniti sličnije stočnim sortama (feed varities) nego pravim pivskim sortama, iako su one zbog drugih agrotehničkih i ekonomskih prednosti vrlo zanimljive proizvođačima, pa tako i selekcionarima ječma. Analiza polaznih ječmova (Tablica 2.) pokaza je da jako dobru masu 1000 zrna za sve ispitivane kultivare (preko 44g) koja je u dobroj korelaciji sa udjelom endosperma zrna tj. u konačnici sa udjelom velikih škrobnih zrnaca koja su najpoželjniji supstrat za amilolizu. Razlog tomu je što su škrob i proteini u endospermu u formalnoj korelaciji (smatra se da se zajedno nadopunjuju do 100), pa povećanjem udjela škroba pada udjel proteina što je za pivarstvo poželjno svojstvo. Pivari drže da je tijekom vegetacijskog perioda bilo dobro tzv. "nalijevanje zrna" što ima i tehnološki i ekonomski povoljan učinak (Peltonen i sur., 1994) (Narziss, 1999). S druge strane niska masa 1000 zrna može ukazivati na stres tijekom vegatacijskog prrioda poznatog kao fenomen prisilnog sazrijevanja zrna koje dovodi do slabijeg nalijevanja zrna i nepovoljne strukture i udjela dušika. Ovo je uzrokovano činjenicom da se tu radi o anaboličkim biokemijskim procesima čija regulacija ne trpi temperaturne stresove, te u tom slučaju dušik iz prihrane ima nepovoljan učinak na kvalitetu zrna (Schuster i sur., 1988). lako su preporučene vrijednosti za ukupne proteine u zrnu $10-11 \%$ te se vrijednosti teško postižu a da se ne naruše važni agronomski pokazatelji kvalitete, najčešće prinos. Bez obzira ne nešto više vrijednosti od preporučenih one su dosta dobre za naše klimatske uvjete. Previsok udjel proteina u zrnu ima brojne štetne posljedice na postupak slađenja (slabija razgradnja zrna) kao i na proces vrenja (Peltonen i sur., 1994) (Shewry i Ullrich, 2014). Ako je masa 1000 zrna uz ovakve vrijednosti za ukupni dušik visoka tada treba obratiti pozornost samo na koncentraciju topljivog dušika u sladovini. Polazna koncentracija $\beta$-glukana bila je vrlo dobra za sorte Vanessa i Lukas dok je za Pivarac bila dosta visoka. Polazna koncentracija $\beta$-glukana u ječmu je u jakoj pozitivnoj korelaciji sa koncentracijom $\beta$-glukana u sladovini samo za dobro poznate i kroz dugi vremenski period praćene pivarske sorte poput Vanesse, 
dok se jare i pivarsko-stočne sorte pokazuju veoma različite vrijednosti, te se polazna koncentracija $\beta$-glukana u zrnu ne može koristiti kao osnova za predikciju $\beta$-glukana u sladu i sladovini (Habschied i sur., 2020). Staklavost zrna je također bila nešto povišena ali je ispitivanjem staklavosti gotovih sladova ustanovljeno da je prolaznog karaktera. Prilikom analize samog procesa mikroslađenja dobiveni su prihvatljivi gubitci za Pivarac i Vanessu, te nešto povišeni za Lukas (Tablica 3.). Naime smatra se da su ukupni gubitci do 10,5\% prihvatljivi za svijetli slad, uz odnos gubitaka oko $2 / 3$ za disanja i $1 / 3$ za klicu s tim da se uobičajeno dobiva odnos nešto pomaknut u korist klice (zavisno od procesnih uvjete tijekom slađenja), razlog tome može biti zato što se često i gubitak suhe tvari zrna od oko 0,5-1\% prilikom močenja pripisuje gubitku na disanje jer se ne može izvagati (Briggs, 1998). Vlaga nakon 48h (kao posredna mjera za moć bubrenja zrna) bi trebala biti oko 45\% (MEBAK, 2011) ali je dobivena nešto niža vrijednost što može imati različite razloge, s tim da treba imati u vidu da analitički priručnici uglavnom daju očekivane vrijednosti za sjevernoeuropske klimatske uvjete tijekom vegetacijskog perioda.

Tablica 2. Analiza kvalitete ječma

Table 2. Analysis of barley quality

\begin{tabular}{|c|c|c|c|}
\hline & \multicolumn{3}{|c|}{ Sorta /Varieties } \\
\hline & $\begin{array}{l}\text { Pivarac } \\
\mathrm{B} / \mathrm{s}-\mathrm{tr}\end{array}$ & $\begin{array}{l}\text { Vanessa } \\
\text { B / w-tr }\end{array}$ & $\begin{array}{l}\text { Lukas } \\
\text { B-Fe / w-tr }\end{array}$ \\
\hline \multicolumn{4}{|l|}{ vlažnost (\%)/ } \\
\hline moisture (\%) & 11,5 & 12,8 & 12,5 \\
\hline $\begin{array}{l}\text { masa } 1000 \text { zrna }(\mathrm{g}) / \\
1000 \text { grain weight }(\mathrm{g})\end{array}$ & 45,2 & 44,4 & 44,4 \\
\hline $\begin{array}{l}\text { Ukupni proteini (\% s.tv.)/ } \\
\text { Total proteins (\% d.wt.) }\end{array}$ & 11,85 & 11,71 & 11,91 \\
\hline $\begin{array}{l}\beta \text {-glukan (g/100 g s.tv.)/ } \\
\beta \text {-glucan (g/100 d.wt.) }\end{array}$ & 4,6 & 3,68 & 3,77 \\
\hline $\begin{array}{l}\text { Staklavost (\%)/ } \\
\text { Vitreosity (\%) }\end{array}$ & 25 & 19 & 29 \\
\hline
\end{tabular}

B (pivarski); Fe (stočni); Fe-B (pivarsko/stočni); H (golozrni) = namjena sorte/ B (brewing); Fe (feed); Fe-B (brewing/ feed); $\mathrm{H}$ (hulless) = end use of varieties; $\mathrm{w}$-tr (ozimi, dvoredi); $\mathrm{w}$-sr (ozimi dvoredi); s-tr (jari, dvoredi); $\mathrm{H}$ (golozrni); = tip sorte/w-tr (winter, two rowed); w-sr (winter, two rowed); s-tr (spring, two rowed); $\mathrm{H}$ (hulless); = tip of varieties;

Analizom slada (Tablica 4.) ustanovljeno je da su sve ispitivane sorte imale vrlo dobru težinu 1000 zrna (>35g) i staklavost (<5\%). Ovdje treba napomenuti da se sladilo dorađeno zrno I klase (sortiranje na $\varnothing 2,05 \mathrm{~mm}$ ). Prhkost ili friabilnost zrna vrlo dobrog, svijetlog pivarskog slada bila je značajno niža od preporučene (>82) što se slaže sa rezultatima dobivenim u istraživanju sladarske kvalitete višenamjenskih sorti domaćeg ječma (Mastanjević i sur., 2017). Razlozi za ovo nisu istraživani, ali bi također mogli biti povezani s fenomenom prisilnog sazrijevanja zrna. Ukupni proteini u sladu bili su za očekivan iznos niži nego u polaznom ječmu, i za naše klimatske uvjete vrlo dobri s obzirom da su za žitarice koje su pred kraj vegetacijskog perioda izložene kombinaciji i visoke vlažnosti i temperature koncentracija ukupnih proteina u sladu ne prati i koncentracija topljivih proteina u sladovini, tj. niže je od očekivane. Jara sorta Pivarac imala 0,8-1\% niži udjel proteina u sladu u odnosu na ozime sorte Vanessu i Lukas. Nadalje, dobivene su vrlo dobre vrijednosti za ekstrakt slada (fini), za Pivarac i Vanessu (preko preporučenih 82\%), dok je Lukas pokazao nešto nižu vrijednost. Za sve ispitivane sorte su dobivene su preporučene vrijednosti za brzinu oćećerenja, bistroću, boju i boju nakon kuhanja, te brzinu cijeđenja kongresna sladovine (filtrabilnost). 
Tablica 3. Pokazatelji kvalitete mikroslađenja (vlaga zelenog slada i gubitci tijekom slađenja)

Table 3. Analysis of micromalting indicators (moisture and losses during malt production)

\begin{tabular}{lccc}
\hline & \multicolumn{3}{c}{ Sorta/Variety } \\
\cline { 2 - 4 } & $\begin{array}{c}\text { Pivarac } \\
\text { B / s-tr }\end{array}$ & $\begin{array}{c}\text { Vanessa } \\
\text { B / w-tr }\end{array}$ & $\begin{array}{c}\text { Lukas } \\
\text { B-Fe / w-tr }\end{array}$ \\
\hline $\begin{array}{l}\text { Vlaga na početku klijanja (\%)/ } \\
\text { Moisture at the beggining of germination phase (\%) }\end{array}$ & 44,5 & 44,5 & 44,5 \\
\hline $\begin{array}{l}\text { Vlaga nakon 48h (\%)/ } \\
\text { Moisture after 48 h (\%) }\end{array}$ & 43,4 & 43,9 & 44,2 \\
\hline $\begin{array}{l}\text { Vlaga zelenog slada (\%)/ } \\
\text { Moisture of green malt (\%) }\end{array}$ & 45,0 & 45,0 & 46,8 \\
\hline $\begin{array}{l}\text { Vlaga slada (\%)/ } \\
\text { Moisture of malt (\%) }\end{array}$ & 4,69 & 4,54 & 5,0 \\
\hline $\begin{array}{l}\text { Ukupnigubitci (g/s.tv.)/ } \\
\text { Total losses (g/ d.wt.) }\end{array}$ & 9,7 & 10,7 & 11,3 \\
\hline $\begin{array}{l}\text { Gubitci na disanje (g/ s.tv.)/ } \\
\text { Respiration losses (g/ d.wt.) }\end{array}$ & 5,5 & 5,4 & 5,1 \\
\hline $\begin{array}{l}\text { Gubitci na klicu (g/ s.tv.)/ } \\
\text { Germination losses (g/d. wt.) }\end{array}$ & 4,2 & 5,3 & 6,2 \\
\hline
\end{tabular}

Dobivene $\mathrm{pH}$ vrijednosti sladovine bile su unutar standardnih vrijednosti od 5,6-6 (MEBAK, 2011), i one prvenstveno zavise od aktivnosti proteaza u zrnu tijekom ukomljavanja. Viskoznost sladovina prelazila je standardnu vrijednost $(<1,55 \mathrm{mPaxs})$ samo za sortu Lukas. Hartongov broj (relativni ekstrakt određen na $45^{\circ} \mathrm{C}$ ) je posredna mjera za aktivnost cjelokupnog enzimskog potencijala slada, prvenstveno citolitičkog i proteolitičkog kompleksa, izuzev aktivnosti $\alpha$-amilaze. Preporučena vrijednost za svijetli slad je preko $36 \%$. Dobivene su više (Pivarac, Vanessa), do značajno više vrijednosti (Lukas) od preporučenih. Razlog ovome traži dodatno istraživanje. Dobivene su vrlo dobre vrijednosti za topljive proteine u sladovini (standardne vrijednosti su 550-750 $\mathrm{mg} / \mathrm{L}$ ), dok su za aminokiselinski dušik ili FAN dobivene značajno više vrijednosti od preporučenih (120-160 mg/100 g suh.tv.). Oko 70\% od ukupnog FAN-a se oslobađa u zrnu tijekom slađenja, a $25-30 \%$ tijekom ukomljavanja (Hill i Stewart, 2019). U posljednje vrijeme se smatra da kvasac relativno dobro podnosi širok raspon koncentracija FAN-a u sladovini, uz uvjet da nije preopterećene za kvasca nevažnim, pa čak i štetnim aminokiselinama poput glicina, prolina i hidroksiprolina. Na slikama 1 i 2 prikazan je porast aktivnost oba enzima tijekom slađenja, dok je njihova aktivnost u gotovom, osušenom i stabiliziranom slada prikazana u Tablici 4. Ustanovljen je nagli porast aktivnosti $\alpha$-amilaze kod svih sorti od prvog do četvrtog dana klijanja, pri čemu se maksimum aktivnosti uspostavlja četvrtog dana. Također sušenjem aktivnost $\alpha$-amilaze opada za oko $10 \%$ kod svih sorti. lako se očekivalo da će jara sorta Pivarac imati najveću aktivnost, ozima sorta Vanessa je pokazala bolji rezultat, dok je Lukas očekivano imao najnižu vrijednost s obzirom da nije striktno pivarska sorta. Sve tri sorte su imale aktivnost $\alpha$-amilaze unutar standardnih vrijednosti (MEBAK, 2011). $\beta$-amilaza je imala blagi porast aktivnosti čiji je maksimum dosegnut otprilike $u$ istom vremenu kada i $\alpha$-amilaze, s tim da je utjecaj sušenja na pad aktivnosti $\beta$-amilaze značajno veći (25-30\%) nego kod $\alpha$-amilaze što ne čudi jer je $\beta$-amilaza puno termonestabilniji enzim. Dobivene vrijednosti za aktivnost $\beta$-amilaze su bile također najviše za Vanessu, ali je zanimljivo da je sorta Lukas imala dosta visoku aktivnost $\beta$-amilaze $s$ obzirom na najnižu aktivnost $\alpha$-amilaze. Vrijednosti za aktivnost $\beta$-amilaze u svim sortama su prelazile gornju granicu $\left(270^{\circ} \mathrm{WK}\right)$ gotovo kao kod slađenja pšenice. Možda se ove vrijednosti mogu objasniti time što se u mikrosladari slade male količine zrna u idealnim uvjetima koje je teže ostvariti u industrijskom postrojenju. Već je spomenuto da se $\alpha$-amilaza sintetizira tijekom klijanja (Hall i sur., 1956; Hardie, 1975; Fincher, 1989; Kuntz i Bamforth, 2007) i porast njezina aktivnosti prati i pojačana razgradnja endosperma, odnosno razgradnje škroba (Evans i sur., 1997). Budući se enzim de-novo sintetizira ova aktivnost brzo raste od 0 u početnoj fazi klijanja do određene vrijednosti koja zavisi i od genotipskih svoj- 
stava sorte i od procesnih uvjeta tijekom slađenja (Fincher, 1989; Kuntz i Bamforth, 2007). Ako se provodi standardizirani postupak mikroslađenja (gdje je utjecaj procesnih uvjeta na svaku sortu ili šaržu jednak) tada možemo međusobno uspoređivati sorte $s$ obzirom na brzinu sintetiziranja i ukupnu aktivnost enzima u gotovom sladu. Dosta je teško procjeniti pojedinačni utjecaj ovih enzima na koncentraciju fermentabilnih šećera i na konačni stupanj prevrenja sladovine, iako je $\beta$-amilaza zapravo enzim za ošećerenje škroba. $\beta$-amilaza već postoji u zrnu i ona se tijekom klijanja samo aktivira (Sopanen i Laurière, 1989; Evans i sur., 1997, 2005; Buttimer i Briggs, 2000). Temperatura želatinizacije škroba ječma (kada postaje dostupan djelovanju amilolitičkih enzima) je $55-65^{\circ} \mathrm{C}$ (Sun i Henson, 1991). Obzirom na optimalnu temperaturu za djelovanje $\alpha$-amilaze (ima viši temperaturni optimum u odnosu na ostale amilolitičke enzime) može se reći da se ovaj enzim uključuje u razgradnju škroba tek u završnoj fazi ukomljavanja (kada se stvara najviše fermentabilnih šećera), tj. ovaj se enzim sintetizira pri nedovoljno visokoj koncentraciji ekstrakta slada koji sadržava fermentabilne šećera, a koji su hrana za sintezu klice i korijenčića (Ullrich i sur., 1997; Duedahl-Olesen i sur., 2000). Stoga bi se moglo očekivati da će velika količina šećera nastati tijekom ukomljavanja prvenstveno zbog aktivnosti $\alpha$-amilaze (Duke i Henson, 2009). Naime, Cauvain, i Young (2009) ustanovili su da je porast aktivnosti $\alpha$-amilaze, $\beta$-amilaze i granične dekstrinaze najveći između 1 i 2 dana klijanja da tijekom cjelokupnog klijanja aktivnost $\alpha$-amilaze korelira puno bolje sa ukupnom koncentracijom šećera u sladu $(r=0.830, P<0.0001)$ nego aktivnost $\beta$-amilaze $(r=0.665, P<0.0001)$ i granične dekstrinaze $(r=0.785, P<0.0001)$ (1).

Tablica 4. Rezultati analize gotovih sladova

Table 4. Results of malt analysis

\begin{tabular}{|c|c|c|c|}
\hline \multirow{2}{*}{$\begin{array}{l}\text { Pokazatelj/ } \\
\text { Quality indicator }\end{array}$} & \multicolumn{3}{|c|}{ Sorta/Variety } \\
\hline & $\begin{array}{c}\text { Pivarac } \\
\mathrm{B} / \mathrm{s}-\mathrm{tr}\end{array}$ & $\begin{array}{l}\text { Vanessa } \\
\text { B / w-tr }\end{array}$ & $\begin{array}{l}\text { Lukas } \\
\text { B-Fe / w-tr }\end{array}$ \\
\hline Vlažnost (\%)/Moisture (\%)/ & 7,6 & 7,6 & 7,5 \\
\hline $\begin{array}{l}\text { masa } 1000 \text { zrna (g/s .tv.)/ } \\
1000 \text { grain weight (g d.wt.) }\end{array}$ & 43,8 & 43,5 & 43,9 \\
\hline Staklavost (\%)/Vitreosity (\%) & 1 & 3,2 & 4 \\
\hline Prhkost (\%)/Friability(\%) & 73 & 72 & 71 \\
\hline Ukupni proteini (g/s .tv.)/Total proteins (\% d.wt.) & 11,2 & 12 & 12,3 \\
\hline Fini ekstrakt (g/s .tv.)/Fine extract content (\% d.wt.) & 83,6 & 82,8 & 81,2 \\
\hline Ošećerenje (min)/Saccharification time (min) & $10-15$ & $10-15$ & $10-15$ \\
\hline Bistroća (EBC u.) Clarity of wort (EBC u.) & 3,1 & 3,0 & 3,1 \\
\hline Boja slada (EBC u.)/Wort colour (EBC u.) & 3,0 & 2,6 & 2,5 \\
\hline Boja nakon kuhanja (EBC u.)/ Colour after cooking (EBC u,) & 4,2 & 3,8 & 3,7 \\
\hline Filtrabilnost (min)/ Filtration time (min) & 55 & 55 & 59 \\
\hline $\mathrm{pH}$ & 5,8 & 5,8 & 5,8 \\
\hline Viskoznost (mPas. 8.6\%e)/ Viscosity (mPas. 8.6\%e) & 1,504 & 1,511 & 1,578 \\
\hline Hartongov broj VZ $45^{\circ} \mathrm{C}(\%) /$ Hartong number VZ $45^{\circ} \mathrm{C}(\%)$ & 38,2 & 37,7 & 40,9 \\
\hline Dijastatska snaga slada $\left({ }^{\circ} \mathrm{WK}\right) /$ Diastatic power $\left({ }^{\circ} \mathrm{WK}\right)$ & 245 & 264 & 241 \\
\hline aktivnost $\alpha$-amilaze (DU)/ $\alpha$-amilaze activity (DU) & 55 & 56 & 53 \\
\hline Konačni stupanj prevrenja (\%)/Final attenuation of wort (\%) & 82,0 & 82,5 & 80,8 \\
\hline Topljivi proteini (mg/L)/Soluble N (mgL) & 548,3 & 540 & 621,7 \\
\hline $\boldsymbol{X}$ amino $\mathrm{N}$ (mg/100 g dry wt.)/FAN (mg/100 g dry wt.) & 161 & 203 & 190 \\
\hline
\end{tabular}

B (pivarski); Fe (stočni); Fe-B (pivarsko/stočni); H (golozrni) = namjena sorte/B (brewing); Fe (feed); Fe-B (brewing/ feed); $\mathrm{H}$ (hulless) = end use of varieties; w-tr (ozimi, dvoredi); w-sr (ozimi šestoredi); s-tr (jari, dvoredi); $\mathrm{H}$ (golozrni); = tip sorte/w-tr (winter, two rowed); w-sr (winter, six rewed); s-tr (spring, two rowed); $\mathrm{H}$ (hulless); = tip of varieties; 


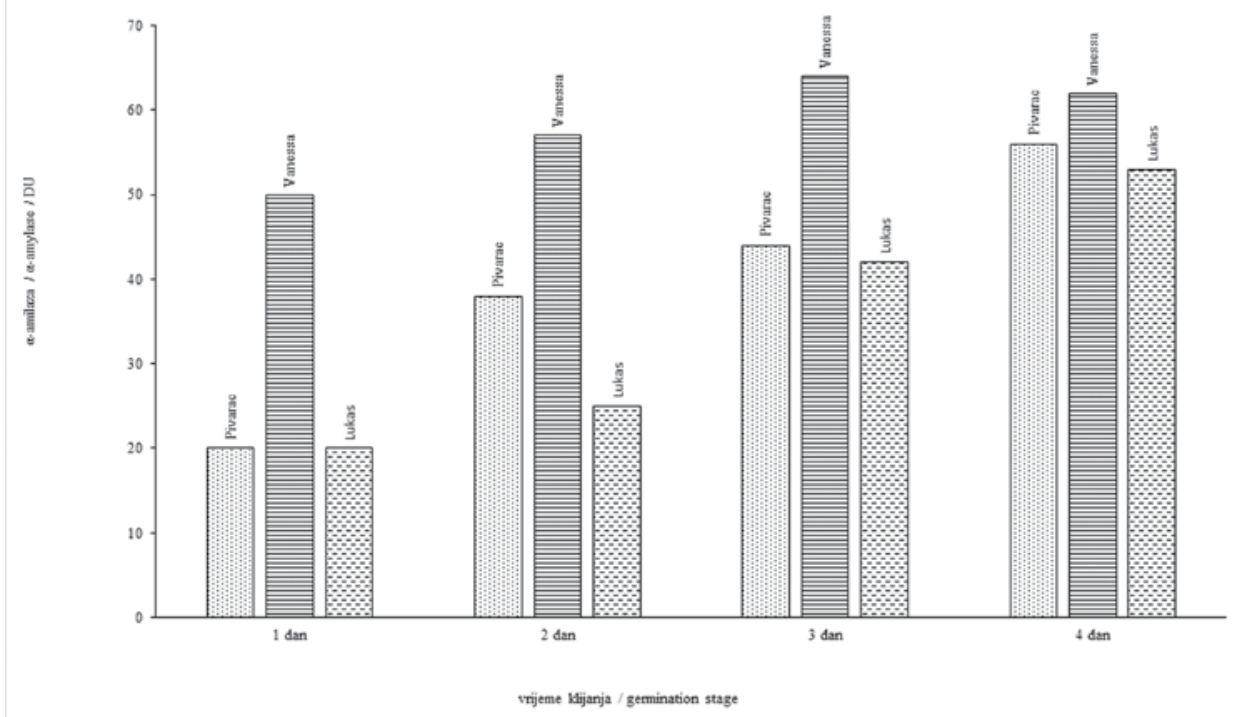

Slika 1. Aktivnost a- amilaze i dijastatska snaga tijekom procesa klijanja Figure 1 Activity of a- amilaze during germination phase

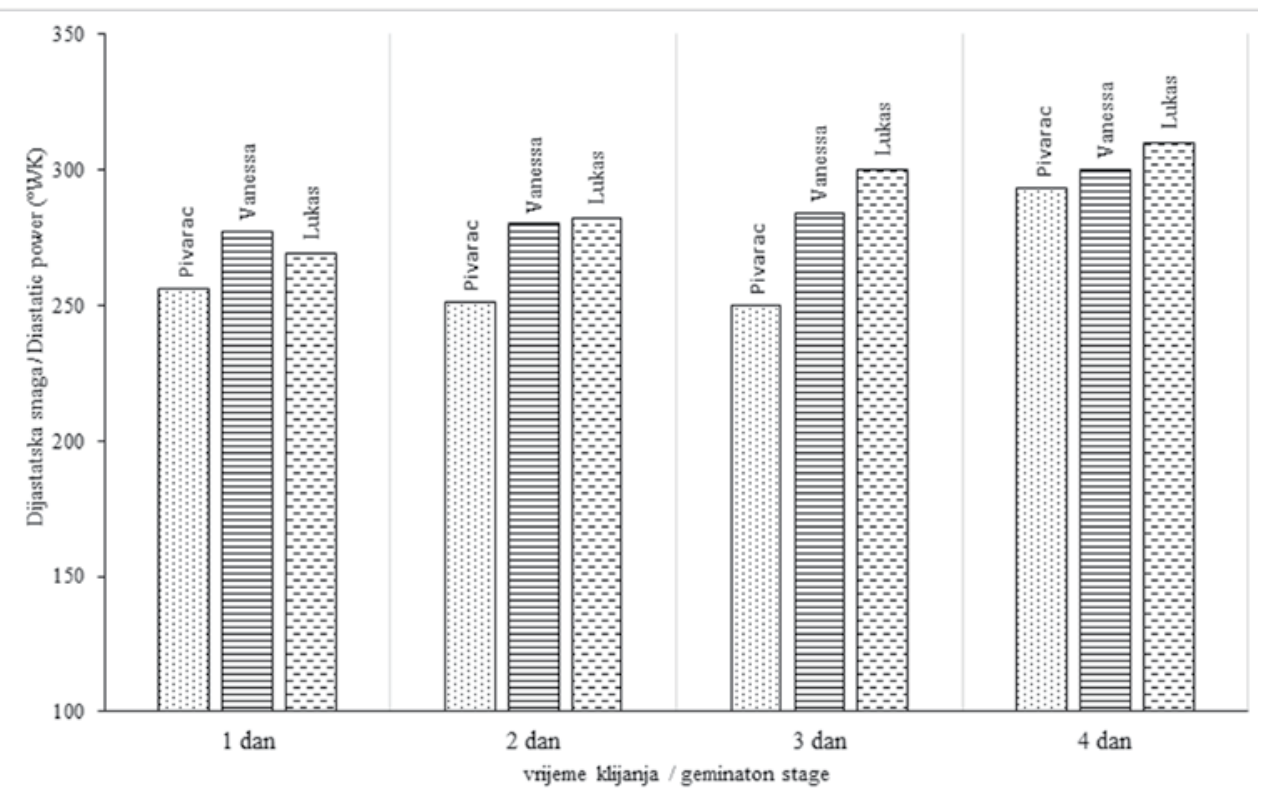

Slika 2 Razvoj dijastatske snage slada tijekom procesa klijanja

Figure 2 Development of diastaticpower of malt during germination phase 
Nadalje, dobili su da je koncentracija pojedinih šećera (glukoze, maltoze, saharoze, fruktoze i maltodekstrina (od maltotrioze do maltoheptaoze) u svim ispitivanim kultivarima bila u puno jačoj korelaciji sa aktivnošću $\alpha$-amilaze tijekom faze klijanja nego sa aktivnošću $\beta$-amilaze ili granične dekstrinaze (za glukozu i maltozu $r=0.872$ odnosno 0.763 i $P<0.0001$ za $\alpha$-amilazu dok je za $\beta$-amilazu $r=0.587$, i 0.679 and $P<0.0001$, te za graničnu dekstrinazu $r=0.806$ i 0.733 and $P<0.0001$ ). Danas se smatra da aktivnost $\alpha$-amilaze korelira značajnije s ukupnom koncentracijom šećera u sladu, kao i sa koncentracijom najvažnijih šećera (maltoza i glukoza).

\section{Zaključak}

Ispitivana je aktivnost $\alpha$-amilaze i $\beta$-amilaze u tri različite sorte ječma (pivarski jari, pivarski ozimi i pivarsko-stočni) koje se koriste u proizvodnji pivarskog slada u Hrvatskoj tijekom faze klijanja i u gotovim sladovima. Također su određivani i pokazatelji kvalitete polaznih ječmova, samog procesa mikroslađenja i gotovih sladova. Ustanovljeno je da sve tri sorte daju svijetli pivarski slad vrlo dobre kvalitete. Neki pokazatelji kvalitete slada poput topljivog dušika u sladovini i viskoznosti su imali izvrsne vrijednosti, najproblematičnije vrijednosti dobivene su za friabilnost dobivenih sladova. Međutim, kako je friabilnost kumulativni pokazatelj na koji utječu brojni pojedinačni faktori ovo zahtijeva dodatna istraživanja. Aktivnost $\alpha$-amilaze u sve tri sorte bila je unutar standardnih vrijednosti za svijetli slad. Njezina aktivnost naglo je rasla između prvog i trećeg dana klijanja s tim da je najviša bila na zadnjeg, četvrtog dana klijanja. Aktivnost $\beta$-amilaze u sve tri sorte bila je viša od standardnih vrijednosti za svijetli slad, te je umjereno rasla tijekom klijanja s tim da je također najvišu aktivnost dosegla u četvrtom danu klijanja. Proces sušenja slada značajno više smanjuje aktivnost $\beta$-amilaze (25-30\%) nego $\alpha$-amilaze (oko 10\%).

\section{Literatura}

Bamforth, C. W. (2006) Scientific Principles of Malting and Brewing. St. Paul, American Society of Brewing Chemists. Briggs, D.E. (1998) Malts and Malting. Springer US.

Buttimer, E.T. and Briggs, D.E. (2000). Mechanisms of the Release of Bound B-Amylase. Journal of the Institute of Brewing, 106 (2), 83-94. https://doi.org/10.1002/j.2050-0416.2000.tb00043.x.

Cauvain, S. P., Young L. S. (2009) The ICC Handbook of Cereals, Flour, Dough, Product Testing (Methods and Applications). Lancaster: DEStech Publications Inc.

Doehlert, D.C. and Duke, S.H. (1983). Specific Determination of $\alpha$-Amylase Activity in Crude Plant Extracts Containing $\beta$-Amylase. Plant Physiology, 71 (2), 229-234. https://doi.org/10.1104/pp.71.2.229.

Doehlert, D.C., Duke, S.H. and Anderson, L. (1982). Beta-Amylases from Alfalfa (Medicago sativa L.) Roots. Plant Physiology, 69 (5), 1096-1102. https://doi.org/10.1104/pp.69.5.1096.

Duedahl-Olesen, L., Pedersen, L.H. and Larsen, K.L. (2000). Suitability and limitations of methods for characterisation of activity of malto-oligosaccharide-forming amylases. Carbohydrate Research, 329 (1), 109-119. https://doi. org/10.1016/s0008-6215(00)00151-8.

Duke, S.H. and Henson, C.A. (2009). A Comparison of Barley Malt Amylolytic Enzyme Activities as Indicators of Malt Sugar Concentrations. Journal of the American Society of Brewing Chemists, 67 (2), 99-111. https://doi.org/10.1094/ ASBCJ-2009-0311-01.

European Brewery Convention and Analysis Committee. (1998). Analytica-EBC. Nürnberg: Verlag Hans Carl.

Evans, D. E., Wallace, W., Lance, R. C. M., MacLeod, L. C. (1997). Measurement ofBeta-amylase in Malting Barley (Hordeum vulgareL.). II. The Effect of Germination and Kilning. Journal of Cereal Science, 26 (2), 241-250. https://doi. org/10.1006/jcrs.1997.0120.

Evans, D. E., Collins, H., Eglinton, J., Wilhelmson, A, (2005). Assessing the Impact of the Level of Diastatic Power Enzymes and Their Thermostability on the Hydrolysis of Starch during Wort Production to Predict Malt Fermentability. Journal of the American Society of Brewing Chemists, 63 (4), 185-198. https://doi.org/10.1094/ASBCJ-63-0185.

Fincher, G.B. (1989). Molecular and Cellular Biology Associated with Endosperm Mobilization in Germinating Cereal Grains. Annual Review of Plant Physiology and Plant Molecular Biology, 40 (1), 305-346. https://doi.org/10.1146/ annurev.pp.40.060189.001513.

Gupta, M., Abu-Ghannam, N. and Gallaghar, E. (2010). Barley for Brewing: Characteristic Changes during Malting, Brewing and Applications of its By-Products. Comprehensive Reviews in Food Science and Food Safety, 9 (3), $318-328$. https://doi.org/10.1111/j.1541-4337.2010.00112.x.

Habschied K., Lalić A., Horvat D., Mastanjević K., Lukinac J., Jukić M., Krstanović V. (2020). $\beta$-Glucan Degradation During Malting of Different Purpose Barley Varieties. Fermentation, 6 (1), 21. https://doi.org/10.3390/fermentation6010021. 
Hall, R.D., Harris, G. and MacWilliam, I.C. (1956). Carbohydrates in Malting and Brewing V. Further Studies on the Carbohydrates of Barley, Malt and Wort. Journal of the Institute of Brewing, 62 (3), 232-238. https://doi. org/10.1002/j.2050-0416.1956.tb02854.x.

Hardie, D.G. (1975). Control of carbohydrase formation by gibberellic acid in barley endosperm. Phytochemistry, 14 (8), 1719-1722.

Henson, C.A. and Duke, S.H. (2008). A Comparison of Standard and Nonstandard Measures of Malt Quality. Journal of the American Society of Brewing Chemists, 66 (1), 11-19. https://doi.org/10.1094/ASBCJ-2007-1210-01.

Hill, A.E. and Stewart, G.G. (2019). Free Amino Nitrogen in Brewing. Fermentation, 5 (1), 22. https://doi.org/10.3390/ fermentation5010022.

Kuntz, R.J. and Bamforth, C.W. (2007). Time Course for the Development of Enzymes in Barley1. Journal of the Institute of Brewing, 113 (2), 196-205. https://doi.org/10.1002/j.2050-0416.2007.tb00276.x.

Mastanjević K., Lenart L., Šimić G., Lalić A., Krstanović V. (2017). Malting quality indicators of Croatian dual-purpose barley varieties. Croatian journal of food science and technology, 9 (2), 145-151. https://doi.org/10.17508/CJFST.2017.9.2.09.

MEBAK $^{\circledR}$ (2011) Methodensammlung der Mitteleuropäischen Analysenkommission; Jacob, F.,Ur.; Selbstverlag der MEBAK $^{\circledR}$ : Freising-Weihenstephan, Gemany.

Peltonen, J. et al. (1994). Hordein and Malting Quality in Northern Barleys. Hereditas, 120 (3), 231-239. https://doi. org/10.1111/j.1601-5223.1994.00231.x.

Sopanen, T. and Laurière, C. (1989). Release and Activity of Bound $\beta$-Amylase in a Germinating Barley Grain. Plant Physiology, 89 (1), 244-249. https://doi.org/10.1104/pp.89.1.244.

Sun, Z. and Henson, C.A. (1990). Degradation of Native Starch Granules by Barley $\alpha$-Glucosidases. Plant Physiology, 94 (1), 320-327. https://doi.org/10.1104/pp.94.1.320.

Sun, Z.T. and Henson, C.A. (1991). A quantitative assessment of the importance of barley seed alpha-amylase, beta-amylase, debranching enzyme, and alpha-glucosidase in starch degradation. Archives of Biochemistry and Biophysics, 284 (2), 298-305. https://doi.org/10.1016/0003-9861(91)90299-x.

Tabatabaei, S.A. (2015). The Changes of Germination Characteristics and Enzyme Activity of Barley Seeds under Accelerated Aging. Cercetari Agronomice in Moldova, 48 (2), 61-67. https://doi.org/10.1515/cerce-2015-0030.

Ullrich, S.E., Han, F. and Jones, B.L. (1997). Genetic Complexity of the Malt Extract Trait in Barley Suggested by QTL Analysis. Journal of the American Society of Brewing Chemists, 55 (1), 1-4. https://doi.org/10.1094/ASBCJ-55-0001.

Prispjelo/Received: 14.7.2020.

Prihvaćeno/Accepted: 30.9.2020.

Professionalpaper

\title{
Development of enzyme potential in different purpose barley varieties during malting
}

\begin{abstract}
The development of enzymatic activity of barley grains during the malting process is one of the key developments which ensures satisfactory technological quality of malt. Numerous studies have been conducted on this topic, which found that the best results related to the development of enzymatic potential of grain are a result of malting purpose, spring, two-row brewing varieties. The application of appropriate malting regime that ensures process conditions favaurable for te activation of already present in the grain and/or de novo synthesis enzymes are also an important factor. The aim of this research was to establish how different purpose, two - row, spring and winter varieties of barley, which are commonly used for malt production in Croatia, react to the above requirements. Based on the obtained results, the $\alpha$-amylase activity in all examined cultivars was found to be within the standard values, while the 6 -amylase activity in all three cultivars was higher than the standard values for light malt. Both enzymes showed the highest activity on the last, fourth day of germination. The malt drying process significantly reduced B-amylase activity (25$30 \%$ ), in comparison to the activity of $\alpha$-amylase (about 10\%). Other indicators of the quality of starting barley, micromalting process and finished malts were also determined. It was found that all three varieties give light malt approprite for malting, reulting with malt of very good quality. Some malt quality indicators such as soluble nitrogen in wort and viscosity had excellent values, and the most problematic indicator was fiability. However, as friability is a cumulative indicator affected by a number of individual factors this requires further research.
\end{abstract}

Keywords: purpose varieties of barley, alpha-amylaze, total distatic power, micromalting 